\title{
Effect of Work Overload on Job Satisfaction Through Burnout
}

\author{
Sofia Prima Dewi ${ }^{1, *}$, Merry Susanti ${ }^{2}$, Sufiyati $^{3}$, Cokki $^{4}$ \\ 1,2,3,4 Faculty of Economics \& Business, Tarumanagara University, Jakarta, Indonesia \\ Email address: \\ sofiad@fe.untar.ac.id,merrys@fe.untar.ac.id,sufiyati@fe.untar.ac.id,\&cokki@fe.untar.ac.id \\ ${ }^{*}$ Corresponding author
}

\begin{abstract}
The current study proposes to search the relationship between work overload, burnout, and job satisfaction for lecturers. The questionnaires were distributed among 69 lecturers at the faculty of economics and business using convenience sampling. Data were processed using Partial Least Square-Structural Equation Modelling (PLS-SEM). The finding indicates that work overload has a positive effect on burnout, but work overload and burnout do not have a negative effect on job satisfaction.
\end{abstract}

Keywords: Burnout; Work Overload; Job Satisfaction.

\begin{abstract}
Abstrak: Penelitian ini bertujuan untuk mencari hubungan antara kelebihan beban kerja, burnout, dan kepuasan kerja bagi dosen. Kuesioner disebarkan kepada 69 dosen Fakultas Ekonomi dan Bisnis dengan menggunakan convenience sampling. Data diolah menggunakan Partial Least Square-Structural Equation Modeling (PLS-SEM). Hasil penelitian menunjukkan bahwa kelebihan beban kerja berpengaruh positif terhadap burnout, namun kelebihan beban kerja dan burnout tidak berpengaruh negatif terhadap kepuasan kerja.
\end{abstract}

Kata kunci: Burnout; Kelebihan Beban Kerja; Kepuasan Kerja.

\section{INTRODUCTION}

Every college strives to become a world-class university. One of the references used by the Ministry of Research, Technology and Higher Education (Kemenristekdikti) to measure the quality of higher education institutions in Indonesia towards world-class universities in QS World University Rankings. For universities to become world-class universities, higher education institutions are required not only to produce generations who master abilities in academics but also have technical analysis skills in the field of humanistic skills and professional skills so that they have added value to be able to compete in the world of work.

In the era of industrial revolution 4.0 which emphasized the phenomenon of disruptive innovation, lecturers played an important role in the learning process. The problem is that the condition of lecturers in Indonesia is still dominated by baby boomers and generation $\mathrm{X}$ who are digital immigrants while the future generations are millennials or digital natives. Therefore, universities are required to produce lecturers who have the following qualifications and competencies: (1) educational competence; (2) competence in 
research; (3) competence for technological commercialization; (4) competence in globalization; and (5) competence in future strategies (http://sumberdaya.ristekdikti.go.id/index.php/2018/01/30/era-revolusi-industri-4-0saatnya-generasi-millennial-menjadi-dosen-masa-depan).

Law of the Republic of Indonesia Number 14 of 2005 article 60 concerning Teachers and Lecturers states that lecturers are obliged to carry out education or teaching, research, and community service. The three main tasks above are often called Tridharma colleges. Before the enactment of Law Number 14 of 2005 concerning Teachers and Lecturers, the main task of lecturers was as an educator or instructor, but with the enactment of Law Number 14 of 2005 concerning Teachers and Lecturers, the role and main tasks of lecturers developed into professional educators and scientists with the main task is to transform, develop, and disseminate knowledge, technology, and art through education or teaching, research, and community service. The main task of lecturers in implementing Tridharma tertiary education is a unity of dharma or activity, because the three activities can only be distinguished but cannot be separated, because they are interrelated and support one another.

The ability to carry out the Tridharma of higher education is important for the career success of a lecturer. The workload of lecturers turned out to be quite excessive and this can be seen from a large amount of teaching in one semester, a large number of research activities and community service activities, and must often actively participate in various committee activities and seminars. This excess workload causes stress on the lecturer. According to (Anisykurlillah et al., 2013), there is a positive impact (eustress) and there is a negative impact (distress). If the lecturer continues to experience stress so that he experiences emotional fatigue and low motivation at work, it will influence the emergence of burnout. The term burnout was first introduced by Herbert Freudenberger in 1974 to describe the form of fatigue that arises because someone works too hard (both time and energy), is dedicated, and does not prioritize one's own needs and desires.

According to (Azeem et al., 2014), (Yo and Surya, 2015), (Budiasih, 2017), (Sarwita and Sopiyan, 2017), (Satrini et al., 2017), (Trisnawati et al., 2017), (Kusuma, 2018), and (Atmaja and Suana, 2019) work overload has a positive effect on burnout. According to (Fieyatiwi et al., 2019), work overload has a negative effect on burnout. According to (Ferdiansyah and Purnima, 2011), work overload does not affect on burnout.

Burnout causes lecturer job satisfaction to decrease. According to (Potale and Uhing, 2015) and (Fieyatiwi et al., 2019) burnout has a positive effect on job satisfaction. According to (Afrizal et al., 2014), (Poniasih and Dewi, 2015), (Wibowo et al., 2015), (Yo and Surya, 2015), (Yuliastini and Putra, 2015), and (Purwanti and Triastity, 2017) burnout have a negative effect on job satisfaction. According to (Amilia and Nugrohoseno, 2014) and (Mawaranti and Prasetio, 2018), burnout does not affect on job satisfaction.

Research on the effect of work overload on job satisfaction through burnout has been widely carried out, but the results obtained indicate inconsistencies. This study is a replication of the research of (Fogarty et al., 2000) and (Murtiasri's, 2007). According to Bacharach et al. (1991), work overload has a positive effect on the job satisfaction of engineers. According to (Ali and Farooqi, 2014), (Mahendrawan and Indrawati, 2015), (Yo and Surya, 2015), (Setianingsih, 2017), and (Udriyah et al., 2018) work overload has a negative effect on job satisfaction. According to (Fogarty et al., 2000) and (Murtiasri, 2007) work overload does not influence on job satisfaction. This study aims to obtain 
empirical evidence regarding (1) The positive effect of work overload on burnout, (2) The negative influence of burnout on job satisfaction, and (3) The negative effect of work overload on job satisfaction.

\section{THEORETICAL REVIEW}

Work Overload. Work overload is one of the dimensions of role stress. According to (Budiasih, 2017), work overload is a condition where someone has a workload that is too much but not under their capabilities and available time. (Setianingsih, 2017) defines work overload as many jobs that must be completed by employees within a certain period time and is the result of work volume and time norms. (Fieyatiwi et al., 2019) concluded that work overload is a condition where workers have too much work and must be completed in a limited time.

According to (Mahendrawan and Indrawati, 2015) workloads that are too heavy or weak physical abilities will hinder employees from working. The capacity of the work should be adjusted according to the number of people working on it. The excessive workload can result in decreased quality of work.

Burnout. According to (Afrizal et al., 2014) stress (burnout) is a consequence of every action and environmental situation that can cause excessive psychological and physical demands on a person. (Velnampy and Aravinthan, 2013) define stress as emotional patterns of cognitive behavior and psychological reactions that can harm and endanger the work, organization, and work environment.

(Goswami, 2015) explains the factors that cause stress are the existence of overtime work and work on holidays, the existence of excessive work pressure in meeting deadlines, not promoted, and changes in work. According to (Potale and Uhing, 2015), the burnout experienced by each employee is different. Stress arises because of his inability to meet the demands and expectations him. Prolonged stress will cause burnout. Burnout is a condition of tension beyond the ability of employees to affect emotions, thought processes, and the condition of a person in carrying out work. Three dimensions that can be used as a benchmark for burnout, namely: (1) Exhaustion (fatigue), characterized by prolonged fatigue both physically, mentally, and emotionally; (2) Cynicism (cynicism), characterized by a cynical attitude and tends to withdraw from the work environment; and (3) ineffectiveness (marked ineffectiveness), characterized by feelings of helplessness, feeling that all tasks assigned are heavy.

According to (Purwanti and Triastity, 2017), burnout can create physical and psychological imbalances. A person's response to stress levels varies even with the same stressors, depending on one's ability to deal with stress. The effects of burnout include the desire to move to work (turnover intention), reduced level of performance (job performance), and dissatisfaction at work (job dissatisfaction). Burnout has a great influence on employee performance, and if not corrected immediately will cause setbacks. The negative effects of burnout are decreased productivity, increased employee absences, higher health insurance costs, and reduced quality and efficiency of employee performance.

According to (Schaufeli and Taris, 2014), burnout can be reduced by adding job resources such as the equitable distribution of information, appreciation from structural 
officials, regular meetings for intellectual discussion, equal opportunities to attend training and seminars, lecturer involvement in decision making related to lecturers, procedural justice, and increase trust in structural officials through the implementation of good corporate governance.

Job Satisfaction. According to (Purwanti and Triastity, 2017) job satisfaction is a person's perspective, both positive and negative, related to their work. (Wibowo et al., 2015) concluded that job satisfaction is a feeling of work and as a result of employee interactions with the work environment. Job satisfaction has a considerable influence on organizational productivity. Five dimensions of job satisfaction, namely: (1) Work itself, where work must provide interesting assignments, opportunities to learn, and opportunities to accept responsibility; (2) Salary, whereby the salary received is deemed appropriate in the company; (3) Promotional opportunities, where there are opportunities to advance in the company; (4) Supervision, where there are supervisors who can provide technical assistance and behavioral support; and (5) Colleagues, where there are coworkers who have the technical expertise and provide social support.

Work Overload Against Burnout. (Atmaja and Suana, 2019) stated that work overload will result in burnout because employees, who are research respondents, become irritable and offended. Employees feel like a failure at work because even though they provide the best service to tourists in restaurants, they are still scolded by superiors. The same thing was stated by (Pratiwi et al., 2019) that the number of tasks that must be done in a limited time or accept a job that is too difficult or beyond the limits of a person's ability will cause physical and mental fatigue that will eventually lead to burnout. With a different research object, namely students, (Kusuma, 2018) found the same thing. Students with a lot of assignments and must be completed in a limited time, causing them to feel exhausted so that their learning achievement has decreased. This shows that the excess workload on students also causes burnout.

However, (Bacharach et al., 1991) found that work overload does not affect on burnout. This is because engineers (who are research respondents) assume they are used to excessive workloads. However, with different respondents, namely the profession as a nurse, (Bacharach et al., 1991) found conflicting results. Their research shows that with excessive workload, nurses feel burnout.

Burnout Against Job Satisfaction. (Afrizal et al., 2014) found that the higher burnout that occurred in employees, the lower employee job satisfaction. This means that burnout has a direct impact on the job satisfaction of the employees concerned. The same thing was found in the study of (Poniasih and Dewi, 2015) that burnout had a negative effect on job satisfaction. (Potale and Uhing, 2015) stated that employees who do not reach psychological maturity will cause frustration that will eventually cause burnout and affect employee job satisfaction. This shows that burnout has a meaning in determining employee job satisfaction.

The results of (Purwanti and Triastity, 2017) research also shows that burnout influences on employee job satisfaction. (Wibowo et al., 2015) in their research confirmed the theory that someone who always strives to achieve targets in his work will affect the work satisfaction of that person. This can be seen from the burnout experienced by the 
employee. This is different from the research of (Amilia and Nugrohoseno, 2014) which states that burnout is not a predictor of employee job satisfaction. (Mawaranti and Prasetio, 2018) stated that employees make burnout as a spirit to achieve targets for themselves and their organizations. Although the work is multiple, they feel comfortable with the profession of work done. This explains that burnout does not affect on job satisfaction.

Work Overload Against Job Satisfaction. (Ali and Farooqi, 2014) stated that work overload will result in poor employee performance so that employees are not satisfied with their work. This statement is not in accordance with research conducted by (Bacharach et al., 1991), where they found the results that work overload causes respondents (engineers) to feel satisfied with their work. This is because, with the excessive workload, they will get a greater income (reward). After all, they receive more projects. However, for the nursing profession, (Bacharach et al., 1991) found different results, where nurses who have excessive workloads feel dissatisfied with their work.

On the other hand, (Murtiasri, 2007) did not find any effect of work overload on job satisfaction, but if through burnout mediation variables it was found that there was an effect of work overload on job satisfaction. A different thing was found by (Mahendrawan and Indrawati, 2015) where employees with excessive workloads would have reduced job satisfaction.

Hypothesis Development. Prior Research. (Barrick, 1989) examined the effect of burnout on job satisfaction. The population used is supervisors in the fields of education, agriculture, economics, marketing, trade, and industry. The total sample used was 171 supervisors and the data was processed using SPSS software. The results showed that the role of overload and the extent of the responsibility of someone who most influences burnout. The higher the level of burnout felt, the level of job satisfaction will decrease. This can be overcome by having communication between leaders and employees, attending seminars and training, and good time management.

(Bacharach et al., 1991) examined the effect of role stress on burnout and job satisfaction. There are two populations used: nurses (a total of 215 questionnaires were distributed and only 35\% returned) and engineers (a total of 430 questionnaires were distributed and $79 \%$ returned). The results showed that for the nurse profession work overload had a positive effect on burnout but for the engineer profession work overload had no effect on burnout. Burnout has a negative effect on job satisfaction in both the nursing profession and the engineer. Work overload on job satisfaction has a positive effect on the engineer profession because if the burden rests more then the engineer will get more rewards from his clients, for example: getting a new project. On the other hand, for the nurse profession, work overload does not affect job satisfaction. This is because, with more workload, nurses do not get additional income.

(Abraham, 1997) examined the effect of the role of stress on job satisfaction with thinking styles as a moderating variable. This study used 146 employees from telecommunications, entertainment, food, and fabric retail companies in South Florida and only 80 employees were sampled. The results showed that role ambiguity had a negative effect on job satisfaction and thinking styles succeeded in moderating the effect of role ambiguity on job satisfaction. Work overload has a negative effect on job satisfaction and 
work overload has a positive effect on job satisfaction with hierarchical styles as a moderating variable.

(Fogarty et al., 2000) examined the effect of the role of stress on burnout. The study population was accountants who were members of the American Institute of Certified Public Accountants (AICPA). The total questionnaire returned and sampled as many as 188 data. The results showed that the role of stress (role conflict, role ambiguity, and role overload) had a positive effect on burnout. Burnout has a negative effect on job satisfaction and performance but has a positive effect on turnover intention. Role conflict has a negative effect on job satisfaction but has a positive effect on performance and turnover intention. Role ambiguity has a positive effect on performance and turnover intention but does not affect job satisfaction. Role overload does not affect job satisfaction and performance but negatively affects turnover intention.

(Brewer and Clippard, 2002) examined the effect of burnout on job satisfaction. This study uses Student Support Services Personnel in the United States as a population with a sample size of 166 respondents. The results showed that emotional exhaustion negatively affected job satisfaction while depersonalization and personal accomplishment did not affect job satisfaction. If the three components of burnout are combined and tested their effects on job satisfaction, it turns out there is no effect. This is due to the sample used which has a low burnout rate and a high level of job satisfaction.

(Buckingham, 2004) examined the relationship between stress, work overload, role conflict, and self-efficacy in principals in Maine. The total questionnaires returned were 496 respondents and were processed using SPSS software. The results showed that $82 \%$ of the total sample experienced moderate (moderate) and high-stress levels. Work overload and role conflict have a positive effect on stress (burnout). Principals with high levels of stress will face tougher challenges, more conflict, and rejection, as well as dissatisfaction with environmental conditions and salaries. To reduce stress levels, (Buckingham, 2004) suggests raising awareness about stress and time management, promoting rewards, reviewing tasks, and responsibilities to ensure the ability to do a job.

(Murtiasri, 2007) developed a role stress model on auditors from 46 public accounting firms in Indonesia. The number of respondents who returned the questionnaire was 166 auditors whose data was then processed using SEM. The results showed that role stressors (role conflict, role ambiguity, and work overload) had a positive effect on burnout. Furthermore, burnout has a negative effect on job satisfaction and job performance but this does not make auditors change workplaces. Role conflict and role ambiguity affect job satisfaction, job performance, and desire to move but work overload do not affect job satisfaction, job performance, and desire to move.

(Rai, 2010) examined the burnout of long-term nursing staff. The questionnaire was distributed to 794 staff and only 363 staff returned the questionnaire. The results showed that the most influential workload (among role stress) on burnout (emotional exhaustion and depersonalization), where more workload resulted in nurses increasingly feeling burnout.

(Ferdiansyah and Purnima, 2011) examined the effect of role ambiguity, role conflict, and work overload on burnout in public accounting firms in the city of Bandung. 47 questionnaire samples were returned from 27 public accounting firms in the city of Bandung. Data processing using SPSS software and the results of the study showed that 
only role conflict had a positive effect on burnout while role ambiguity and work overload did not affect burnout.

(Wright et al., 2011) examined the burnout of doctors who also work as lecturers. The total number of doctors who filled out the questionnaire was 212 out of 300 doctors, but only 201 could be used as a sample. The results showed that around $21 \%$ of respondents experienced moderate to high burnout. However, burnout that occurs is not caused by the long hours worked but by decreased job satisfaction, increased job insecurity, and increased workload.

(Dasgupta, 2012) examined the effect of role ambiguity, role conflict, and work overload on burnout by mediating self-efficacy against nurses in private hospitals. The total sample used was 146 of which 44 came from nurses who served in the critical care unit. Data processing is performed using SPSS software. The results showed that work overload, role conflict, and role ambiguity had a positive effect on burnout. Work overload, role conflict, role ambiguity, and burnout have a negative relationship with selfefficacy. Work overload, role conflict, role ambiguity, and burnout will have a negative effect on nurses' performance and also the quality of services provided by nurses.

(Yurur and Sarikaya, 2012) researched the effect of work overload, role ambiguity, and social support on burnout on social workers in Turkey. The total sample used was 222 social workers consisting of 110 women and 112 men. The results showed that work overload and role ambiguity had a positive effect on burnout while social support had a negative effect on burnout.

(Utami and Nahartyo, 2013) examined whether auditor personality increases burnout. Respondents were 58 auditors working in public accounting firms in Yogyakarta, Semarang, Jakarta, and Palembang. The results showed that work overload had a positive effect on burnout and personality type A moderated the effect of work overload on burnout. This happens because auditors with personality type A will be impatient in completing tasks that result in the emergence of burnout.

(Afrizal et al., 2014) tested the effect of a work conflict and work stress (burnout) on the job satisfaction of employees of the PT TASPEN (PERSERO) Malang branch. This study uses SPSS software in processing data on the results of questionnaires distributed to 36 employees. The results showed that work conflict and work stress (burnout) had a negative effect on job satisfaction. (Afrizal et al., 2014) suggested implementing conflict management in managing conflicts that occur in organizations and creating conditions of a work environment conducive to dealing with work stress (burnout) using a stress management approach.

(Ali and Farooqi, 2014) examined the effect of work overload on job satisfaction and the effect of job satisfaction on employee performance and employee engagement. This research was conducted at the Public Sector University for the Gujranwala division in Pakistan. The population consists of lecturers and non-lecturer staff. The total sample used was 2,017 with $42 \%$ taken from lecturers and the remaining $58 \%$ from non-lecturer staff. The results showed that work overload had a negative effect on job satisfaction. Also, job satisfaction has a positive effect on employee performance and employee engagement. Ali and Farooqi (2014) stated that employees who experience work pressure due to more workload will experience dissatisfaction with their work. To overcome this, organizations must understand the needs of employees, motivate employees by providing the necessary 
appreciation and training. Excessive workload will affect intellectual and social abilities. With the use of technology, it is expected that the workload can be further reduced.

(Amilia and Nugrohoseno, 2014) examined the effect of organizational culture and job stress (burnout) on employee job satisfaction. This research was conducted at PT Kereta Api Indonesia Persero DAOP 8 Surabaya and obtained a sample of 79 employees which were processed using SPSS software. The results showed that only organizational culture had a positive effect on employee job satisfaction while job stress (burnout) did not affect on employee job satisfaction. This is because employees at PT Kereta Api Indonesia Persero DAOP 8 Surabaya experience work stress that is still within normal limits because it is supported by good organizational culture, such as the existence of innovation and the courage of risk-taking by leaders, employees who are considered capable of being promoted, results from orientation with completing tasks quickly and well, employees are given education and training related to their duties, and there is support from the leadership and colleagues so they can work well.

(Azeem et al., 2014) examined the effect of the role of stress on burnout by using nurses in private hospitals as a population. The total samples that can be used are 135 respondents. The results showed that role overload occupies the top position compared to other stressors, role insufficient, role ambiguity, and role boundary. This study concludes that all roles of stress have a positive effect on burnout. The nurses used as the study sample experienced moderate levels of stress which caused them to experience moderate levels of burnout as well. If nurses experience burnout, then patients at the hospital will also suffer because they are not treated properly and professionally.

(Yongkang et al., 2014) examined the relationship between role conflict, role ambiguity, work overload, and job stress (burnout) for civil servants in Beibei, Chongqing. The sample consisted of 165 men and 55 women. Data is processed using SPSS software. The results showed that role conflict, role ambiguity, and work overload had a positive effect on job stress (burnout).

(Mahendrawan and Indrawati, 2015) examined the effect of work overload and compensation on PT Panca Dewata Denpasar's job satisfaction. The entire population of 47 employees was used as a sample. The results showed that work overload had a negative effect on job satisfaction while compensation had a positive effect on job satisfaction.

(Poniasih and Dewi, 2015) researched PT Indonesia Power UBP Bali to see the effect of work motivation, communication, and work stress (burnout) on job satisfaction. This study used 150 employees by conducting interviews, observations, and distributing questionnaires. Data is processed using SPSS software. The results showed that work motivation and communication had a positive effect on job satisfaction while job stress (burnout) had a negative effect on job satisfaction.

(Potale and Uhing, 2015) examined the effect of compensation and job stress (burnout) on the job satisfaction of employees of PT Bank Sulut Utama Manado Branch. The questionnaire was distributed to 105 employees and only 88 employees were used in data processing using path analysis to test hypotheses. The results showed that compensation and job stress (burnout) had a positive effect on job satisfaction.

(Romadhoni et al., 2015) examined the effect of work overload, work environment, and social support on librarian burnout in the city of Mataram. A sample of 76 librarians and data were processed using SPSS software. The results showed that work overload had 
a positive effect on burnout while the work environment and social support had a negative effect on burnout.

(Sari, 2015) examined the relationship of work overload, demographic factors, locus of control, and self-esteem to burnout syndrome in implementing nurses at IRD Sanglah Hospital. The sample used in the study was 53 people who were also the population. The results showed that there was a relationship between work overload, age, marital status, years of service, locus of control, and self-esteem with burnout syndrome, but there was no relationship between sex and education level with burnout syndrome.

(Tziner et al., 2015) examined work stress and turnover intention among hospital doctors by using burnout and job satisfaction as mediating variables. 170 questionnaires were distributed and 124 questionnaires were returned, consisting of 62 male doctors and 62 female doctors. Data were processed using AMOS 7. The results showed that work stress has a positive effect on burnout. Burnout has a negative effect on job satisfaction and job satisfaction has a negative effect on turnover intention. Someone who works in the health sector will face a variety of demands that will cause pressure (both from the hospital, patients, and yourself) that will cause burnout due to ongoing stress so that job satisfaction will also decrease.

(Wibowo et al., 2015) examined the effect of work stress (burnout) on job satisfaction and employee organizational commitment. This research was conducted on 66 employees who worked at UD Ulam Sari, Denpasar. Data is processed using PLS with a variance-based approach. The results showed that work stress (burnout) had a negative effect on both job satisfaction and organizational commitment. Job satisfaction has a positive effect on organizational commitment.

(Yo and Surya, 2015) examined the effect of work overload on job satisfaction with work stress (burnout) as a mediating variable. The study was conducted on employees at PT Lianinti Abadi in Denpasar. A population of 55 employees was used as a sample. Data were analyzed using path analysis. The results showed that work overload and work stress (burnout) had a negative effect on job satisfaction. Work overload has a positive effect on work stress (burnout). The indirect effect of work overload on job satisfaction through work stress (burnout) also provides the same results.

(Yuliastini and Putra, 2015) examined the effect of emotional exhaustion (burnout) on the job satisfaction of vocational teachers of the Technology and Industry Group in Denpasar. The total population of 386 teachers and data processed using SPSS software amounted to 196 teachers. The results showed that emotional exhaustion (burnout) had a negative effect on job satisfaction. This shows that teachers who experience emotional exhaustion, due to student behavior that is difficult to manage and do not want to listen to the teacher's explanation in class and superiors who do not motivate teachers in their work, cause teacher job satisfaction decreases.

(Budiasih, 2017) examines burnout to auditors in Bali. The total population is all public accounting firms in Bali and 105 respondents were returned who returned the questionnaire. The collected data is processed using SPSS software. The results showed that role conflict, role ambiguity, and work overload had a positive effect on burnout.

Research on the influence of transformational leadership style, organizational climate, and work stress on nurses' job satisfaction in Surakarta Regional Mental Hospital (RSJD) was conducted by (Purwanti and Triastity, 2017). The total population of 225 nurses and only 80 nurses were used as samples. Data is processed using SPSS software. 
The results showed that the transformational leadership style and organizational climate had a positive effect on job satisfaction while job stress had a negative effect on job satisfaction. The leader in the Surakarta RSJD acts as a trainer and cares for nurses and helps in the development of nurse talents so that nurses' job satisfaction also increases. Likewise, the organizational climate at Surakarta Central Hospital where hospital management gave awards to nurses who were able to complete their duties well so that job satisfaction also increased. (Purwanti and Triastity, 2017) provide suggestions that stress management can be applied by giving sufficient time for vacation and leave to nurses and also adjusting the responsibilities of each nurse so that stress levels can be suppressed.

(Sarwita and Sopiyan, 2017) examined the effect of role ambiguity and work overload on the burnout of permanent lecturers and DPK in Majalengka University. Data processing is performed using SPSS software. The results showed that role ambiguity and work overload had a positive effect on burnout. To reduce burnout, lecturers must determine work priorities, maintain relationships with colleagues and leaders, create a conducive work climate, and improve lecturer qualifications.

(Satrini et al., 2017) examined the effect of work overload, role ambiguity, and organizational culture on work stress (burnout). The study was conducted on civil servants at the Bali Provincial Statistics Office. The total population is 274 employees and the sample used is 159 employees. The results showed that work overload and role ambiguity had a positive effect on work stress (burnout) while organizational culture had a negative effect on work stress (burnout).

(Setianingsih, 2017) examines work overload and motivation towards job satisfaction of PNS and non-PNS employees. The sample of DKI Jakarta Provincial Health Service Employee Health Service employees is 45 respondents while the non-PNS employee is 38 respondents. The results showed that work overload negatively affected the job satisfaction of both PNS and non-PNS employees. On the other hand, motivation has a positive effect on the job satisfaction of both PNS and non-PNS employees.

(Trisnawati et al., 2017) examined the effect of role stress types on auditor performance with burnout as intervening in public accounting firms in Bali. The sample used was 41 of the 50 questionnaires returned by respondents. Data is processed using PLS. The results showed that role conflict and role ambiguity had a negative effect on auditor performance, while excess roles did not affect on auditor performance. Role conflict, role ambiguity, and work overload positively influence burnout. Burnout has a negative influence on auditor performance. Burnout can mediate the effects of role conflict, role ambiguity, and work overload on auditor performance.

(Kusuma, 2018) examined the effect of work overload on burnout with spiritual intelligence as a mediating variable in S1 Accounting students. A total of 120 questionnaires were distributed but only 117 questionnaires were returned and 112 questionnaires were processed using MRA. The results showed that work overload had a positive effect on burnout. Spiritual intelligence can weaken the influence of work overload on burnout.

(Mawaranti and Prasetio's, 2018) was carried out at UPT Puskesmas Jasinga Bogor to see the impact of stress on job satisfaction. Questionnaires were distributed to 112 respondents and 108 returned were then processed using SPSS software. The results showed that work stress did not affect on job satisfaction. This shows that employees at the UPT Puskesmas Jasinga Bogor do not feel any pressure at work and feel satisfied 
working at the company due to superiors who always motivate, salaries and benefits provided according to work, and they like their work.

(Udriyah et al., 2018) examined the effect of work overload, work-family conflict, and job insecurity on job satisfaction and its impact on the turnover intention at PT Binanusana Internusa Semarang. The number of samples used as respondents was 100 employees. Data processing using path analysis with SPSS software. The results showed that work overload, work-family conflict, and job insecurity had a negative effect on job satisfaction. Work overload, work-family conflict, and job insecurity have a positive effect on turnover intention while job satisfaction has a negative effect on turnover intention.

(Atmaja and Suana, 2019) examined the effect of work overload on burnout with role stress as a mediating variable on Rumors Restaurant employees in Seminyak, Bali. The entire population of 58 employees was sampled and data were processed using SPSS software. The results showed that work overload had a positive effect on burnout.

(Fieyatiwi et al., 2019) examined the effect of a healthy lifestyle on psychological well-being and its impact on auditors. The study was conducted on public accounting firms in Surabaya and Malang. Total auditors returned 110 questionnaires, which were then processed using PLS. The results showed that role ambiguity and role conflict had a positive effect on burnout, while work overload had a negative effect on burnout. Burnout has a negative effect on psychological well-being but has a positive effect on job satisfaction, job performance, and turnover intention. A healthy lifestyle has a positive effect on vitality and vitality has a positive effect on psychological well-being and it does not affect psychological well-being.

Framework and Hypothesis. The model in this research is:

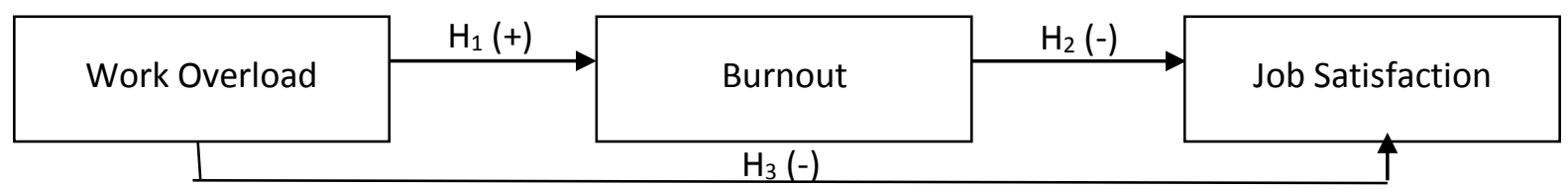

Figure 1. Research Framework

Work overload is a condition where employees feel that there is too much work to be done in a limited time. Work overload has a negative impact on employees, namely the stress level of employees will increase (Yongkang et al., 2014). If the employee experiences ongoing stress, the employee will experience burnout syndrome (Fieyatiwi et al., 2019 and Fogarty et al., 2000). This study uses lecturers as a population. Lecturers have the main task as a teacher is transferring knowledge to students. But, in addition to the main task as a teacher, lecturers also have other duties, namely: examining students' assignments and examinations, guiding and testing, being an academic advisor, conducting research and community service, and attending seminars and workshops to improve their knowledge. With so many tasks that must be completed each semester, the lecturer can experience prolonged stress due to excessive workload. Thus it can be concluded that lecturer overload has a positive influence on burnout. This statement is supported by the results of research by (Azeem et al., 2014), (Yo and Surya, 2015), (Budiasih, 2017), (Sarwita and Sopiyan, 2017), (Satrini et al., 2017), (Trisnawati et al., 
2017), (Kusuma, 2018), and (Atmaja and Suana, 2019). Based on the explanation above, a hypothesis is formed, namely:

H1: Work overload has a positive effect on burnout.

According to (Murtiasri, 2007) and (Tziner et al., 2015) job satisfaction shows an emotional condition where an employee feels happy in doing his work or when assessed his work. (Tziner et al., 2015) further explain if a person experiences ongoing stress then dissatisfaction will arise from his work. If a lecturer experiences stress in his work then it will result in the lecturer not being able to complete his assignment better than in a condition without stress. This shows burnout has a negative influence on job satisfaction. This statement is supported by the results of (Afrizal et al., 2014), (Poniasih and Dewi, 2015), (Wibowo et al., 2015), (Yo and Surya, 2015), (Yuliastini and Putra, 2015), and (Purwanti and Triastity, 2017). Based on the explanation above, a hypothesis is formed, namely:

H2: Burnout has a negative influence on job satisfaction.

(Ali and Farooqi, 2014) found in their research that lecturers who have overloaded work experience dissatisfaction with their work. This is because the lecturer does not get an incentive for the excess workload. Besides that, with excessive workload, lecturers do not have free time for themselves. The results of this study are reinforced by (Yo and Surya, 2015) that the employee workload is not excessive causing employees to be satisfied with their work. Thus, it can be concluded that work overload has a negative effect on job satisfaction. This statement is supported by the results of research by (Ali and Farooqi, 2014), (Yo and Surya, 2015), (Mahendrawan and Indrawati, 2015), (Setianingsih, 2017), and (Udriyah et al., 2018). Based on the explanation above, a hypothesis is formed, namely:

H3: Work overload has a negative effect on job satisfaction.

\section{METHODS}

Population and Sampling Method. The population in this study were permanent lecturers of private universities in West Jakarta. This study uses probability sampling as a sampling method, which means that each lecturer still has the same opportunity to be selected as a sample. The sampling technique used is convenience sampling.

Data Collection Technique. The data collection technique in this study was to use a questionnaire distributed to permanent lecturers. The questionnaire was distributed to 150 lecturers, but only 69 questionnaires were returned for processing. This questionnaire consists of 41 indicators. Work overload consists of 5 indicators according to the study of (Bacharach et al., 1990) and (Buckingham, 2004). Burnout consists of 16 indicators according to the research of (Demerouti et al., 2010). Job satisfaction consists of 20 indicators according to the research of (Weiss et al., 1967). 


\section{RESULTS}

Descriptive Statistic. Based on the average of the variable latent value, the condition of lecturers in the faculties of economics and business shows a low work overload, quite low burnout, and high job satisfaction (Table 1).

Table 1. Mean

\begin{tabular}{lcc}
\hline \multicolumn{1}{c}{ Variable } & Mean & Description \\
\hline Work overload & 2,678 & Low \\
Burnout & 3,015 & Quite low \\
Job satisfaction & 5,400 & High \\
\hline
\end{tabular}

Structural Model Testing (Inner Model). Before testing the structural model (inner model), first testing the measurement model (outer model). The measurement model testing results indicate that all variables passed the validity and reliability tests.

Multicollinearity. There is no multicollinearity between work overload (RO) and burnout $(\mathrm{Bu})$ variables (Table 2).

Table 2. Variance Inflation Factor (VIF)

\begin{tabular}{lcc}
\hline \multicolumn{1}{c}{ Variable } & VIF & Description \\
\hline $\mathrm{JS}=\mathrm{f}(\mathrm{RO}, \mathrm{Bu})$ & 2,262 & No multicollinearity \\
$\mathrm{RO}$ & 2,262 & No multicollinearity \\
$\mathrm{Bu}$ & & \\
\hline
\end{tabular}

Adjusted R2. The ability of the work overload variable to explain variations in the burnout variable is moderate, while the ability of the work overload and burnout variables to explain variations in work satisfaction variables is none (Table 3).

Table 3. Adjusted $\mathrm{R}^{2}$

\begin{tabular}{lcc}
\hline \multicolumn{1}{c}{ Variable } & Adjusted $\mathbf{R}^{2}$ & Description \\
\hline Burnout & 0,558 & Moderate \\
Job Satisfaction & 0,183 & None \\
\hline
\end{tabular}

Hypothesis Testing 1. Work overload (RO) has a positive, significant, and strong influence on burnout $(\mathrm{Bu})$ (Table 4). This means that if a lecturer feels overloaded, the lecturer will feel burnout very much and this applies to all permanent lecturers.

Table 4. Hypothesis Testing Results 1

\begin{tabular}{cll}
\hline Variable & \multicolumn{1}{c}{ Value } & Description \\
\hline \multirow{3}{*}{$\mathrm{RO} \rightarrow \mathrm{Bu}$} & $\beta=0,747$ & Positive \\
& $\mathrm{p}$-value $=0,000$ & Significant \\
& $\mathrm{f}^{2}=1,262$ & Strong \\
\hline
\end{tabular}


Hypothesis Testing 2. Burnout $(\mathrm{Bu})$ has a negative, insignificant, and insignificant effect on job satisfaction (JS) (Table 5). This means that if a lecturer experiences burnout, his job satisfaction will decrease significantly. This influence does not apply to all permanent lecturers.

Table 5. Hypothesis Testing Results 2

\begin{tabular}{cll}
\hline Variable & \multicolumn{1}{c}{ Value } & \multicolumn{1}{c}{ Description } \\
\hline \multirow{3}{*}{$\mathrm{Bu} \rightarrow \mathrm{JS}$} & $\beta=-0,147$ & Negative \\
& $\mathrm{p}$-value $=0,303$ & Insignificant \\
& $\mathrm{f}^{2}=0,012$ & No effect \\
\hline
\end{tabular}

Hypothesis Testing 3. Work overload (RO) has a negative, insignificant, and weak influence on job satisfaction (JS) (Table 6). This means that if a lecturer feels overloaded, his job satisfaction will decrease, but this influence is weak and does not apply to all permanent lecturers.

Table 6. Hypothesis Testing Results 3

\begin{tabular}{cll}
\hline Variable & \multicolumn{1}{c}{ Value } & \multicolumn{1}{c}{ Description } \\
\hline \multirow{3}{*}{$\mathrm{RO} \rightarrow \mathrm{JS}$} & $\beta=-0,306$ & Negative \\
& $\mathrm{p}$-value $=0,099$ & Insignificant \\
& $\mathrm{f}^{2}=0,051$ & Weak \\
\hline
\end{tabular}

\section{DISCUSSION}

The result of hypothesis 1 testing is that work overload has a positive effect on burnout. This influence is strong and applies to all permanent lecturers. This influence also occurs in other professions such as nurses (Bacharach et al., 1991; Rai, 2010; Dasgupta, 2012; Azeem et al., 2014), principals (Buckingham, 2004), accountants (Fogarty et al., 2000), auditors (Murtiasri, 2007; Utami and Nahartyo, 2013; Budiasih, 2017; Trisnawati et al., 2017; Fieyatiwi et al., 2019), social workers (Yurur and Sarikaya, 2012), civil servants (Yongkang et al., 2014; Satrini et al., 2017), employees (Yo and Surya, 2015; Atmaja and Suana, 2019), lecturers (Sarwita and Sopiyan, 2017), students (Kusuma, 2018), and librarians (Romadhoni et al., 2015). The results showed that workload overload can cause burnout in lecturers. Based on the indicators used, it can be seen that the biggest cause that can cause lecturers to feel overloaded is when their job as a lecturer interferes with their personal life. Work that is supposed to be done in the office but also done at home and this certainly reduces the time to gather with family. The second reason is that lecturers have limited time to do their work, this may be due to sudden notification. This sudden notification made the lecturer with limited time finally do his job in a hurry to fulfill the Tridharma obligation of higher education. The high excess workload also makes it difficult for lecturers to distinguish between lecturers and family time.

In general, the cause of burnout due to overwork can be due to the absence of additional income for additional workload, lack of or non-existent support from management, weak personal abilities, and capacities, and lack of time to complete work. Burnout can be overcome by additional income to increase workload, communication with 
structural officials and colleagues, providing training and seminars, and good time management. We suspect the causes of burnout for permanent lecturers are (1) There is an additional income that is not commensurate with the increase in workload, (2) Lack of communication between structural officials and lecturers, (3) Lack of equal opportunities for each lecturer in participating in training and seminars, and (4) Lecturers find it difficult to arrange a time to complete their work due to the sudden and uneven distribution of information. Burnout can be reduced by adding job resources (Schaufeli and Taris, 2014). Job resources include routine meetings for intellectual discussion, appreciation from structural officials, equal opportunities to take part in training and seminars, equitable distribution of information, the involvement of lecturers in decision making related to lecturers, procedural justice, and increasing confidence in structural officials through implementation of good corporate governance.

The result of hypothesis 2 testing is burnout does not have a negative effect on job satisfaction. This influence is meaningless and does not apply to all permanent lecturers. These results contradict (Barrick's, 1989) study, (Bacharach et al., 1991), (Fogarty et al., 2000), (Murtiasari, 2007), (Dasgupta, 2012), (Afrizal et al., 2014), (Poniasih and Dewi, 2015), (Tziner et al., 2015), (Wibowo et al., 2015), (Yo and Surya, 2015), (Yuliastini and Putra, 2015), (Purwanti and Triastity, 2017), and (Trisnawati et al., 2017). In general, there is no influence of burnout on job satisfaction can also be caused by superiors always innovating, motivating and supporting, dare to take risks, support from colleagues, salary and benefits in accordance with work, promotion based on results, as well as education and training (Amilia and Nugrohoseno, 2014; Mawaranti and Prasetio, 2018). If you look at the latent value of the variable, it can be seen that the level of burnout at the faculty of economics and business is low and the level of job satisfaction at the faculty of economics and business is high.

The results of this study are also in line with research by (Brewer and Clippard, 2002) where the burnout rate is low and the level of job satisfaction is high. Burnout is ongoing stress where there is a stress that has a positive / eustress effect and there is a negative/distress effect (Anisykurlillah et al., 2013). In the lecturer profession, an example of positive stress is the reporting of lecturer performance burdens which reflects the performance of a college Tridharma lecturer. Reporting the burden of lecturer performance raises a high burnout for lecturers, but financial benefits from reporting the burden of lecturer performance will increase job satisfaction. An example of negative stress on a lecturer is to follow too many committees at the same time as compensation is not commensurate. Another example is the high teacher and student ratio which results in burnout for lecturers and decreased job satisfaction.

This study proposes that burnout does not always affect job satisfaction. The effect of burnout on job satisfaction may depend on the characteristics of the job itself. The faculty of economics and business structural might want to consider to reduce work that does not generate additional income and increase job resources such as communication between officials and lecturers, equal opportunities for training and seminars, and distribute of more organized and even information.

The result of hypothesis 3 testing is that work overload has no negative effect on job satisfaction. This influence is weak and does not apply to all permanent lecturers. These results contradict the research of (Dasgupta, 2012), (Ali and Farooqi, 2014), (Mahendrawan and Indrawati, 2015), (Yo and Surya, 2015), (Setianingsih, 2017), and 
(Udriyah et al., 2018). The main work overload of a lecturer is implementing Tridharma tertiary institutions totaling 12 credits. The excess workload of a lecturer includes teaching more than 12 credits and being involved in many committees. This excess workload will reduce job satisfaction, but financial compensation received will reduce the decrease in job satisfaction. This result is in line with the engineer profession where the income of engineers will increase when the workload increases (Bacharach et al., 1991).

Managerial Implication. Lecturers in the faculty of economics and business that used as a research object have low work overload, quite low burnout, and high job satisfaction. This condition resulted in only work overload has a positive effect on burnout but work overload and burnout have no effect on job satisfaction. The implication of this research to the faculty of economics and business structural that they might want to consider to reduce work that does not generate additional income and increase job resources such as communication between officials and lecturers, equal opportunities for training and seminars, and distribution of more organized and even information. This research can be used as an input for other faculties who have the same characteristics.

Theoretical Implications. In general, the results of previous studies indicate that work overload and burnout influence job satisfaction. In contradiction to previous researches, this study proposes that work overload and burnout do not always affect job satisfaction. In this study, the sample used is the teaching profession. The characteristics of this profession are more similar to the characteristics of the engineer profession where the addition of work overload is accompanied by additional income so that the addition of work overload does not cause a significant decrease in job satisfaction. Similar to previous researches, the effect of burnout on job satisfaction may depend on the characteristics of the job itself. For further research, it is necessary to consider whether the profession used as a sample has the characteristics where the increase in work overload is accompanied by the additional income. Future studies can examine work engagement besides burnout (Hakanen et al., 2019).

\section{CONCLUSION}

The conclusion that can be drawn from the previous discussion is that work overload has a positive effect on burnout, burnout has no negative effect on job satisfaction, and work overload has no negative effect on job satisfaction. This study did not examine other variables such as role ambiguity, role conflict, job performance, and turnover intention. Future studies can examine the role of ambiguity, role conflict, job performance, and turnover intention variables. The sampling technique does not involve all permanent lecturers. The sampling technique for further research is preferably by the census. Burnout can be reduced by adding job resources such as regular meetings for intellectual discussion, appreciation from structural officials, equal opportunities to attend training and seminars, equitable distribution of information, lecturer involvement in decision making related to lecturers, procedural justice, and increasing trust in structural officials through the implementation of good corporate governance. 


\section{REFERENCES}

Abraham, R. (1997). Thinking styles as moderators of role stressor-job satisfaction relationships. Leadership \& Organization Development Journal, 18(5), 236-243.

Afrizal, P. R., Musadieq, M. A., dan Ruhana, I. (2014). Pengaruh konflik kerja dan stres kerja terhadap kepuasan kerja (studi pada karyawan PT Taspen (persero) cabang Malang). Jurnal Administrasi Bisnis, 8(1), 1-10.

Ali, S., and Farooqi, Y. A. (2014). Effect of work overload on job satisfaction, effect of job satisfaction on employee performance and employee engagement (A case of public sector university of Gujranwala division). International Journal of Multidisciplinary Sciences and Engineering, 5(8), 23-30.

Amilia, S. P. N., dan Nugrohoseno, D. (2014). Pengaruh budaya organisasi dan stres kerja terhadap kepuasan kerja karyawan pada PT Kereta Api Indonesia persero DAOP 8 Surabaya. Jurnal Bisnis dan Manajemen, 7(1), 26-33.

Anisykurlillah, I., Wahyudin, A., dan Kustiani. (2013). Pengaruh role stressor terhadap komitmen organisasi dengan kepuasan kerja sebagai variabel intervening pada kantor akuntan publik (KAP) di Jawa Tengah. Jurnal Dinamika Akuntansi, 5(2), 109-120.

Atmaja, I. G. I. W., dan Suana, I. W. (2019). Pengaruh beban kerja terhadap burnout dengan role stress sebagai variabel mediasi pada karyawan rumours restaurant. $E$ Jurnal Manajemen Unud, 8(2), 7775-7804.

Azeem, S. M., Nazir, N. A., Zaidi, Z. B. A., and Akhtar, N. (2014). Role of stress and burnout among nurses in the private hospitals. International Journal of Academic Research in Business and Social Sciences, 4(3), 420-428.

Bacharach, S. B., Bamberger, P., and Conley, S. (1990). Work processes, role conflict, and role overload: The case of nurses and engineers in the public sector. Work and Occupations, 17(2), 199-228.

Bacharach, S. B., Bamberger, P., and Conley, S. (1991). Work-home conflict among nurses and engineers: Mediating the impact of role stress on burnout and satisfaction at work. Journal of Organizational Behavior, 12(1), 39-53.

Barrick, R. K. (1989). Burnout and job satisfaction of vocational supervisors. Journal of Agricultural Education, 35-41.

Brewer, E. W., and dan Clippard, L. F. (2002). Burnout and job satisfaction among student support services personnel. Human Resource Development Quarterly, 13(2), 169186.

Buckingham, D. A. (2004). Associations among stress, work overload, role conflict, and self-efficacy in maine principals. An Abstract of The Thesis Presented in Partial Fulfillment of The Requirements for The Degree of Doctor of Education (in Educational Leadership).

Budiasih, I. G. A. N. (2017). Burnout pada auditor di kantor akuntan publik provinsi Bali. Jurnal Riset Akuntansi dan Keuangan, 5(3), 1589-1600.

Dasgupta, P. (2012). Effect of role ambiguity, conflict and overload in private hospitals' nurses' burnout and mediation through self-efficacy. Journal of Health Management, 14(4), 513-534. 
Demerouti, E., Mostert, K., and Bakker, A. B. (2010). Burnout and work engagement: A thorough investigation of the independency of both constructs. Journal of Occupational Health Psychology, 15(3), 209-222.

Ferdiansyah, and Purnima, I. R. (2011). Pengaruh role ambiguity, role conflict, dan role overload terhadap burnout (Studi empiris pada auditor di KAP kota Bandung). Jurnal Sains Manajemen \& Akuntansi, 3(2), 1-17.

Fieyatiwi, R. S., Diana, N., dan Afifuddin. (2019). Pengaruh gaya hidup sehat terhadap psychological well-being dan dampaknya pada auditor KAP (Studi empiris pada auditor kantor akuntan publik di kota Surabaya dan Malang). E-JRA, 08(05), 97-108.

Fogarty, T. J., Singh, J., Rhoads, G. K., and Moore, R. K. (2000). Antecedents and consequences of burnout in accounting: Beyond the role stress model. Behavioral Research in Accounting, 12, 31-67.

Goswami, T. G. (2015). Job Stress and its effect on employee perfomance in banking sector. Indian Journal of Commerce \& Management Studies, 6(2), 51-56.

Hakanen, J. J., Ropponen, A., De Witte, H., and Schaufeli, W. B. (2019). Testing demands and resources as determinants of vitality among different employment contract groups. A study in 30 European countries. International Journal of Environmental Research and Public Health, 16(24), 1-17.

Kusuma, B. H. (2018). Pengaruh role overload terhadap burnout dengan kecerdasan spiritual sebagai variabel moderasi: Studi empiris pada mahasiswa S1 Akuntansi. Jurnal Akuntansi Bisnis, 11(2), 132-139.

Mahendrawan, I. G., dan Indrawati, A. D. (2015). Pengaruh beban kerja dan kompensasi terhadap kepuasan kerja PT. Panca Dewata Denpasar. E-Jurnal Manajemen Unud, 4(11), 3936-3961.

Mawaranti, R., dan Prasetio, A. P. (2018). Dampak stres kerja terhadap kepuasan kerja pada pegawai UPT Puskesmas Jasinga. JRMB, 13(1), 37-45.

Murtiasri, E. (2007). Anteseden dan konsekuensi burnout pada auditor: Pengembangan terhadap role stress model. Jurnal Maksi, 7(2), 131-149.

Poniasih, N. L. G., dan Dewi, A. A. S. K. (2015). Pengaruh motivasi kerja, komunikasi dan stres kerja terhadap kepuasan kerja karyawan. E-Jurnal Manajemen Unud, 4(6), 1560-1573.

Potale, R., dan Uhing, Y. (2015). Pengaruh kompensasi dan stres kerja terhadap kepuasan kerja karyawan pada PT Bank Sulut cabang utama Manado. Jurnal EMBA, 3(1), 6373.

Pratiwi, I. Y., Ratnadi, N. M. D., Suprasto, H. B., and Sujana, I. K. (2019). The effect of role conflict, role ambiguity, and role overload in burnout government internal supervisors with tri hita karana culture as moderation. International Research Journal of Management, IT and Social Sciences, 6(3), 61-69.

Purwanti, N., dan Triastity, R. (2017). Pengaruh gaya kepemimpinan transformasional, iklim organisasi dan stres kerja terhadap kepuasan kerja perawat di rumah sakit jiwa daerah Surakarta. Jurnal Manajemen Sumber Daya Manusia, 11(1), 134-147.

Rai, G. S. (2010). Burnout among long-term care staff. Administration in Social Work, 34(3), 225-240.

Romadhoni, L. C., Asmony, T., dan Suryatni, M. (2015). Pengaruh beban kerja, lingkungan kerja, dan dukungan sosial terhadap burnout pustakawan di kota 
Mataram. Jurnal Ilmu Perpustakaan, Informasi, dan Kearsipan Khizanah AlHikmah, 3(2), 125-145.

Sari, N. L. P. D. Y. (2015). Hubungan beban kerja, faktor demografi, locus of control dan harga diri terhadap burnout syndrome pada perawat pelaksana IRD RSUP Sanglah. COPING Ners Journal, 3(2), 51-60.

Sarwita, H. A., dan Sopiyan, P. (2017). Pengaruh role ambiguity, role overload terhadap burnout dosen tetap dan dpk di lingkungan Universitas Majalengka. Jurnal Ilmiah Manajemen \& Akuntansi, 4(2), 99-107.

Satrini, I. D. A. K., Riana, I. G., dan Subudi, I. M. (2017). Pengaruh work overload, ambiguitas peran dan budaya organisasi terhadap stres kerja. E-Jurnal Ekonomi dan Bisnis Universitas Udayana, 6(3), 1177-1204.

Schaufeli, W. B., and Taris, T. W. (2014). A critical review of the job demands-resources model: implications for improving work and health. Bridging Occupational, Organizational and Public Health, 43-68.

Setianingsih, A. (2017). Beban kerja dan motivasi terhadap kepuasan pegawai PNS dan non-PNS. Jurnal Ilmu Kesehatan Masyarakat, 6(4), 171-179.

Trisnawati, M., Ramantha, I. W., dan Sari, M. M. R. (2017). Pengaruh jenis role stress pada kinerja auditor dengan burnout sebagai intervening pada KAP di Bali. Jurnal Buletin Studi Ekonomi, 22(2), 187-199.

Tziner, A., Rabenu, E., Radomski, R., and dan Belkin, A. (2015). Work stress and turnover intentions among hospital physicians: The mediating role of burnout and work satisfaction. Journal of Work and Organizational Psychology, 31, 207-213.

Udriyah, Riyadi, dan Utaminingtyas, R. R. B. (2018). Pengaruh beban kerja, work-family conflict dan job insecurity terhadap kepuasan kerja serta dampaknya terhadap turnover intention di PT Binabusana Internusa Semarang. Admisi \& Bisnis, 18(3), 163- 182.

Utami, I., and Nahartyo, E. (2013). auditors'personality in increasing the burnout. Journal of Economics, Business, and Accountancy Ventura, 16(1), 161-170.

Velnampy, T., and Aravinthan, S. A. (2013). Occupational stress and organizational commitment in private banks: A Sri Lankan experience. European Journal of Business and Management, 5(7), 254-267.

Weiss, D. J., Dawis, R. V., England, G. W., and Lofquist, L. H. (1967). Manual for the minnesota satisfaction questionnaire. University of Minnesota.

Wibowo, I. G. P., Riana, G., dan Putra, M. S. (2015). Pengaruh stres kerja terhadap kepuasan kerja dan komitmen organisasional karyawan. E-Jurnal Ekonomi dan Bisnis Universitas Udayana, 4(2), 125-145.

Wright, J. G., Khetani, N., and Stephens, D. (2011). Burnout among faculty physicians in academic health science centre. Paediatr Child Health, 16(7), 409-413.

Yo, P. M. P., dan Surya, I. B. K. (2015). Pengaruh beban kerja terhadap kepuasan kerja dengan stres kerja sebagai variabel mediasi. E-Jurnal Manajemen Unud, 4(5), 11491165.

Yongkang, Z., Weixi, Z., Yalin, H., Yipeng, X., and Liu, T. (2014). The relationship among role conflict, role ambiguity, role overload and job stress of Chinese middlelevel cadres. Chinese Studies, 3(1), 8-11.

Yuliastini, N. W. D., dan Putra, M. S. (2015). Pengaruh kelelahan emosional terhadap kepuasan kerja guru SMK di Denpasar. E-Jurnal Manajemen Unud, 4(4), 943-959. 
Yurur, S., and Sarikaya, M. (2012). The effect of workload, role ambiguity, and social support on burnout among social workers in Turkey. Administration in Social Work, $36(5), 457-478$. 